\title{
ニルバジピン固体分散体錠の無包装状態での安定性
}

\author{
平沢憲幸, * 石瀬早世子，宮田ひとみ
}

\section{Stability of Nilvadipine Solid Dispersion Tablet with Non-Packaging Condition}

\author{
Noriyuki HiRASAwa, ${ }^{*}$ Sayoko IsHISE, and Hitomi MiYATA \\ Research and Development Center, Nichi-iko Pharmaceutical Co., Ltd., \\ 205-1 Shimoumezawa, Namerikawa 936-0857, Japan
}

(Received September 22, 2003; Accepted October 29, 2003)

\begin{abstract}
Nilvadipine (NIL) solid-dispersion tablets were stored counter to packaging instructions by exposing them to $40^{\circ} \mathrm{C}$, $25^{\circ} \mathrm{C}, 75 \%$ relative humidity, and light. The dissolution, stability assay, and tablet properties (weight, thickness and hardness) were then examined. NIL dissolved more than $85 \%$ after all storage periods with exposure to high temperature and humidity. Powder X-ray diffraction analysis indicated that NIL was present in an amorphous state as in the initialstate. The stability assay of NIL showed that it was more than $99 \%$ stable during all storage periods when exposed to temperature, humidity, and light, indicating good stability. Tablet properties were influenced by humidity more than by temperature, and the hardness of tablets decreased with time to $42.9 \mathrm{~N}$ after storage of 3 months.
\end{abstract}

Key words_— nilvadipine; stability; solid dispersion; tablet; conditions counter to packaging instructions

\section{緒言}

固体分散体は難水溶性薬物の溶解性・バイオアベ イラビリティを改善する方法として盛んに研究され ているが，本技術を利用して市販されている製品は 少なく，その理由は以下の 2 つが原因と考えられ る. ${ }^{1)}$ 第 1 に，固体分散体中で薬物は多くの場合, 非晶質として存在するが，保存中に結晶化すること により溶解性が著しく低下する場合が多く, その結 果，低吸収性となり期待された薬効が得られなくな ること. 非晶質が結晶化する外的要因は温度と湿度 であり，特に湿度は非晶質の結晶化に対して大きな 影響を与える. ${ }^{2,3)}$ 第 2 に, 粘着性を有する固体分散 体粉末を錠剤に適用した場合，即溶出型の製剤を得 ることが難しいことが挙げられる.

医薬品の承認申請を目的に実施される安定性試験 は, 流通段階での品質管理を目的として PTP やピ ローを施した最終包装で実施されるが，近年，製剤 の最終包装を取り除き一包化調剤を実施するに当た り, 無包装状態での安定性情報の提供が切望されて いる. ${ }^{4)}$ 固体分散体技術を適用した製剂の場合, 無

日本医薬品工業株式会社医薬開発センター e-mail: n-hirasawa@ nichiiko.co.jp
包装状態で保存されることにより溶解性の低下が最 も桐念される。

筆者らは温度・湿度に対し物理的に安定な固体分 散体製剤を設計することを目標に, 難水溶性薬物で あるニルバジピン（NIL）をクロスポビドン（clPVP) とメチルセルロース（MC）を担体として使 用した 3 成分系固体分散体粉末とすることで, NIL の高溶解度を加温・加湿条件下で経時的に維持する ことが可能となることを見出した. ${ }^{5)}$ 本研究では, この知見に基づき製剤設計された NIL 固体分散体 錠を無包装状態で保存し, 温度, 湿度及び光に対す る安定性（溶出性, 定量, 錠剂物性) について調べ た。なお，無包装状態での安定性試験条件として は, 既に多くの医薬品が収載・評価されている条件 を設定して実施した。 ${ }^{6}$

\section{実 験 の 部}

1. 試料 ニルバジピン固体分散体錠剂として, 1 錠中にニルバジピン $4 \mathrm{mg}$ を含有する製剤（ニバ ディップ錠 4, Lot no. EI101, 日本医薬品工業）を 使用した。 NIL (ダイト), cl-PVP (Polyplasdone XL-10, ISP Japan), MC (メトローズ SM-25, 信 越化学), エタノール (製造用グレード), 乳糖 (ダ 
イラクトーズ S, フロイント産業), 低置換度ヒド ロキシプロピルセルロース（LH-11, 信越化学), ステアリン酸マグネシウム (日本油脂)を使用した. その他の試薬・試液は特級又は HPLC 用を使用し た.

\section{2. 固体分散体錠剤の製造 固体分散体の製造} は溶媒法により調製し，1 ロットは 4 バッチにより 構成した. NIL $(0.6 \mathrm{~kg})$ をエタノール $(21.6 \mathrm{~kg})$ に $40^{\circ} \mathrm{C}$ にて溶解させ，この溶液に cl-PVP $(2.4 \mathrm{~kg})$ 及び MC $(2.4 \mathrm{~kg})$ を分散させ造粒用溶媒とした。 乳糖 $(11.7 \mathrm{~kg})$, 低置換度ヒドロキシプロピルセル ロース（7.5 kg）及び MC（1.8 kg）を高速攪汼造 粒機（FS-GS-50JE, 深江パウテック）に仕込み, 造粒溶媒の半分量を添加してアジテーター 300 $\mathrm{rpm}$, チョッパー $3000 \mathrm{rpm}$ の条件で 5 分間造粒を 行った。 得られた造粒物を流動乾燥機（FLF-120, フロイント産業）で乾燥させ， 22 メッシュの篩で 整粒した後, 高速攪拌造粒機に再投入し, 造粒溶媒 の残量を添加し, 上述した操作条件にて造粒, 乾燥 及び整粒し, 固体分散体造粒物を得た. 固体分散体 造粒物を 4 バッチ分とステアリン酸マグネシウム $(1.2 \mathrm{~kg})$ を $\mathrm{V}$ 型混合機（1000 リットル, 岩黒製作 所）で混合し，ロータリー式打錠機（AQUARIUS3 0839，菊水製作所）を使用し， 1 錠 $178 \mathrm{mg}$ に て打錠を行った。得られた錠剤をハイコーター (HCF130，フロイント産業）により， 1 錠 $10 \mathrm{mg}$ のフィルムコーティングをした.

\section{3. 物理混合物の調製核錠の処方になるよう} に, NIL, cl-PVP, MC, 乳糖, 低置換度ヒドロキシ プロピルセルロース及びステアリン酸マグネシウム を量り, 乳鉢中で混合し物理混合物とした。なお, プラセボ物理混合物は, 核錠処方から NILを除い た成分で構成した。

4. 保存条件製剤の無包装状態での安定性6) を調べるため, 以下の保存条件で錠剤を保存した。

温度 : 錠剂をスクリューキャップ付の褐色ガラス瓶 （マルエム）に入れ密栓し, 恒温器（インキュベー ターIS-81, ヤマト科学) で $40^{\circ} \mathrm{C}$ に保存した。

湿度：錠剤をシャーレに並べ開放下にて, 恒温恒湿 器（LHL-112M，タバイエスペック）で $25^{\circ} \mathrm{C}, 75$ \%相対湿度（R.H.）にて保存した.

光：錠剤を透明プラスチック容器に入れ，120万 Lux・hr を照射した. なお, 照射光には色比較・検
査用 D65 蛍光ランプ（東芝）を使用した.

5. 溶出試験 溶出試験器 (NTR-VS6P, 富山 産業）を使用し, 試験液に精製水 $900 \mathrm{ml}$ を使用し $37 \pm 0.5^{\circ} \mathrm{C}$ においてパドル回転速度 $50 \mathrm{rpm} に て$ 実 施した. 溶出試験開始 30 分後にサンプリングし, 孔径 $0.45 \mu \mathrm{m}$ のメンブランフィルター（DISMIC$25 \mathrm{HP}$, 東洋濾紙）でろ過し, NILの溶出率を HPLCにて測定した。 HPLCは送液ポンプ (L-7100, 日立), 検出器 (UV-8000, 東ソー), カ ラムオーブン (CO-8000, 東ソー), オートインジ エクター（AS-8020, 東ソー), データ処理装置 （C-R6A，島津製作所）により構成した。移動相に は pH 7.4 のリン酸塩緩衝液・メタノール・アセト ニトリル混液（7：7：6）を使用し, 流速はニルバ ジピンの保持時間が 5 分となるように調整し， 242 $\mathrm{nm}$ にて測定を行つた.

\section{6. 粉末 $\mathbf{X}$ 線回折測定錠剤中における NIL} の結晶性を確認するために, 粉末 X 線回折を測定 した。なお，錠剤はフィルムコーティング層をカッ ターナイフで取り除き，核錠部分を乳鉢で粉砕し測 定試料とした。粉末 X 線回折装置には RINT-2000 （理学電気）を使用し, 測定条件は, $\mathrm{X}$ 線源： $\mathrm{CuK} \alpha$, 電圧 : $40 \mathrm{kV}$, 電流 : $40 \mathrm{~mA}$, 走査速度 : $0.5^{\circ} / \mathrm{min}$ で行った.

7. 定量 20 錠の重量を精密に量り試料粉末 とし, ニルバジピン $4 \mathrm{mg}$ 相当の量を精密に量り内 部標準溶液（アセナフテンのアセトニトリル溶液 $(1 \rightarrow 313)) 10 \mathrm{ml}$ を加えた後, 薄めたアセトニトリ ル $(1 \rightarrow 2)$ を加えて $100 \mathrm{ml}$ とし, 超音波処理した 後, 遠心分離し, 上澄液を試料溶液とした。 HPLC は, 溶出試験に記載した機器により構成した。移動 層はリン酸水素二アンモニウム $1.25 \mathrm{~g}$ を精製水 500 $\mathrm{ml}$ に溶かし, テトラブチルアンモニウムヒドロキ シド試液 $5 \mathrm{ml}$ を加え, 薄めたリン酸 $(1 \rightarrow 10)$ で pH 7.0 に調整し, さらにアセトニトリル $600 \mathrm{ml}$ を 加えた。流速は $1.0 \mathrm{ml} / \mathrm{min}$ で, $254 \mathrm{~nm}$ にて測定を 行つた.

8. 錠剂物性錠剂の重量, 厚み, 硬度は錠剂 物性測定器（TM3-3, 菊水製作所）を使用して測定 した.なお，錠剤硬度は直径方向から測定した。

\section{結 果. 考 察}

1. 溶出性 NIL 固体分散体錠を無包装状態 
で, 温度及び湿度に暴露したときの溶出性の経時変 化を Fig. 1 に示した。溶出性の評価基準として は，製剤の規格として設定した溶出試験開始 30 分 後の溶出率（溶出率： $85 \%$ 以上適合）を採用した. 保存 3 カ月の間, 温度又は湿度に暴露した条件のす べての時点で $85 \%$ 以上の溶出率を示し，製剤の溶 出規格を十分に満たした。また，経時的に溶出率が 低下する傾向も認められず，溶出性は無包装状態で 安定であることが示され，これは 3 カ月間の保存期 間中も，NIL の安定な非晶質が保持されているこ とを示唆するものである．製剤中での NIL の結晶 性を確認するために，粉末 X 線回折を測定し結果 を Fig. 2 に示した。結晶質の NIL は粉末 X 線回折

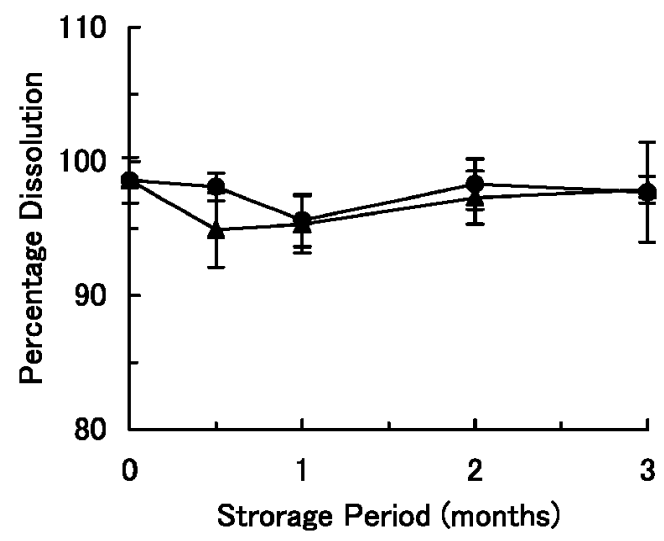

Fig. 1. Dissolution Percentage of NIL from Solid Dispersion Tablets during Storage

- $40^{\circ} \mathrm{C}, \boldsymbol{\Delta}: 25^{\circ} \mathrm{C}, 75 \%$ R.H.
で多くの鋭い回折ピークを示すが, 7) 錠剤中には同 様に回折ピークを有する添加剤が含まれている。 そ こで結晶質の NIL を含有している物理混合物（a） と NIL を含有しないプラセボ物理混合物（b）の粉 末 X 線回折パターンを比較し, 製剤中の NIL の結 晶状態を評価するために, 添加剤と分離・検出が可 能な NIL 結晶由来の回折ピークを探した。その結 果，図中に矢印で示した NIL 由来の $2 \theta=9.8,11.5$, 13.7 及び $23.6^{\circ}$ の回折ピークは物理混合物では観察 されるが，NIL を含有しないプラセボ物理混合で は観察されなかった。したがって，これらの回折 ピークを製剤中での NIL の結晶性を評価するため に使用した。固体分散体錠剂の開始時（c）及び無 包装状態で $25^{\circ} \mathrm{C} ， 75 \%$ R.H. に 3 力月保存した試料 （d）はともに上述した NIL 由来の回折ピークは観 察されず，NIL は非晶質状態で存在していること が示された.

したがって，これらの結果は NIL 固体分散体錠 剂中には NIL, cl-PVP, MC の他に乳糖，低置換度 ヒドロキシプロピルセルロース，ステアリン酸マグ ネシウムを含有するが，無包装状態で温度及び湿度 に暴露した場合でも NIL は開始時と同様に非晶質 状態を安定に維持し，固体分散体技術により意図さ れた溶出性が得られることを示した.

2. 化学的安定性（定量） NIL 固体分散体錠 を無包装状態で温度, 湿度及び光に暴露して保存し たときの定量值の推移を Table 1 に示した。温度及

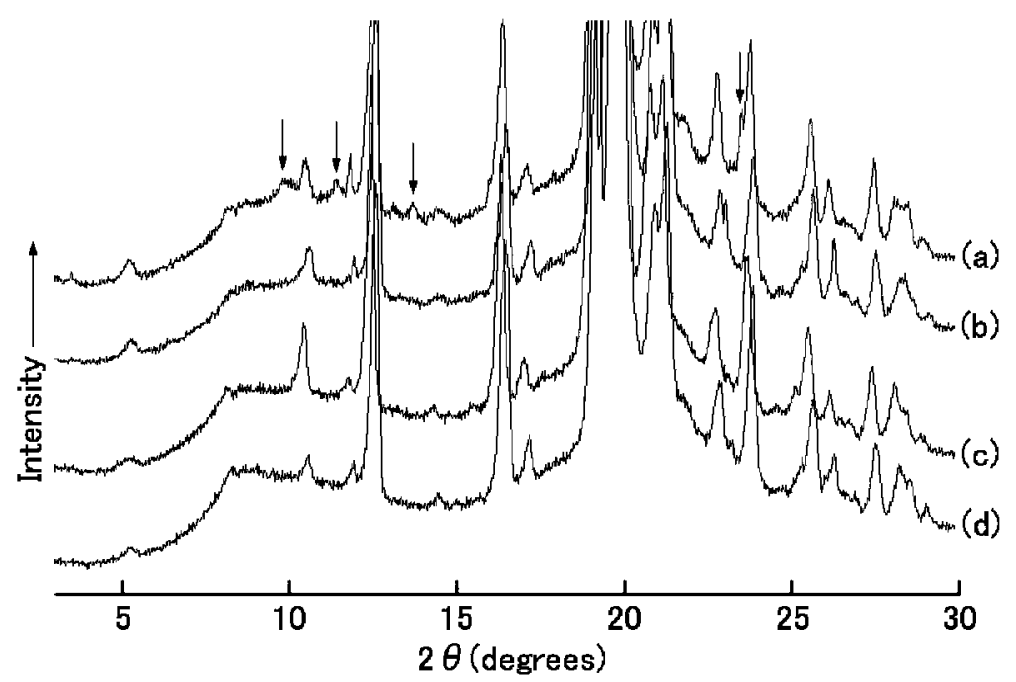

Fig. 2. Powder X-ray Diffraction Patterns

(a) Physical mixture, (b) Placebo physical mixture, (c) Solid dispersion tablet initial, (d) Solid dispersion tablet after storage of 3 months $\left(25^{\circ} \mathrm{C}, 75 \%\right.$ R.H.) . Arrows indicating the presence of crystalline NIL. 
Table 1. Assay of NIL Solid Dispersion Tablets with Non-Packaging Conditions

\begin{tabular}{lccccc}
\hline \hline \multirow{2}{*}{ Storage condition } & \multicolumn{5}{c}{ Storage period (months) } \\
\cline { 2 - 6 } & 0 & 0.5 & 1 & 2 & 3 \\
\hline $40^{\circ} \mathrm{C}$ & $99.8 \%$ & $99.4 \%$ & $99.8 \%$ & $99.7 \%$ & $98.9 \%$ \\
$25^{\circ} \mathrm{C}, 75 \%$ R.H. & $99.8 \%$ & $99.4 \%$ & $99.4 \%$ & $99.3 \%$ & $99.0 \%$ \\
Light & $99.8 \%$ & $99.2 \% a)$ & $99.5 \% b)$ & - & - \\
\hline
\end{tabular}

a) Overall illumination was 0.6 million Lux $\cdot \mathrm{hr}, b$ ) Overall illumination was 1.2 million Lux $\cdot \mathrm{hr}$.
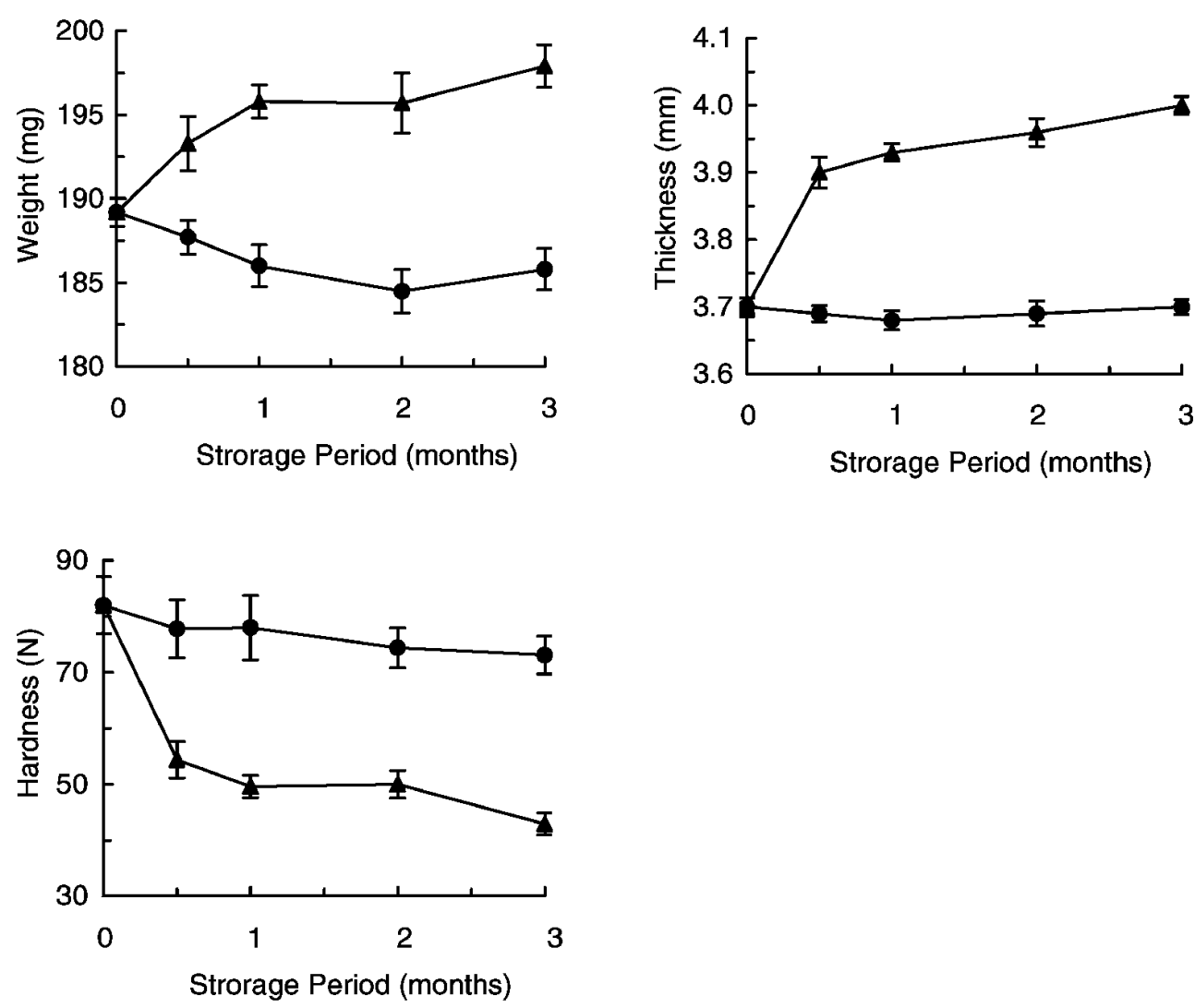

Fig. 3. Tablet Properties of NIL Solid Dispersion Tablets during Storage : $40^{\circ} \mathrm{C}, \boldsymbol{\Delta}: 25^{\circ} \mathrm{C}, 75 \%$ R.H.

び湿度に暴露した場合において，3 カ月間定量值は 低下することはなくいずれの時点においても約 99 \%以上の定量值を示した. また，光に暴露した場合 には，保存 $0.5,1$ カ月でそれぞれ総照射量が 60 万, 120 万 lux • hr に達し, いずれも $99 \%$ 以上の定量值 を示した. したがって, 無包装状態で温度, 湿度及 び光に暴露した場合でも化学的に安定であることが 示された。

3. 錠剂物性（重量, 厚み, 硬度） NIL 固体 分散体錠を無包装状態で温度及び湿度に暴露したと きの錠剤物性（重量, 厚み, 硬度）の経時変化を
Fig. 3 に示した。錠剤重量は加温下 $\left(40^{\circ} \mathrm{C}\right)$ では開 始時の $189.2 \mathrm{mg}$ から徐々に減少し 3 力月後には $185.8 \mathrm{mg}$ になり, 加湿下 $\left(25^{\circ} \mathrm{C}, 75 \%\right.$ R.H. $)$ では 徐々に増加し, 3 力月後には $197.9 \mathrm{mg}$ であった. 錠剂厚みは加温下 $\left(40^{\circ} \mathrm{C}\right)$ ではほとんど変化せず一 定の值を示したが，加湿下 $\left(25^{\circ} \mathrm{C}, 75 \%\right.$ R.H. $)$ で は開始時の $3.70 \mathrm{~mm}$ から 0.5 力月で $3.90 \mathrm{~mm}$ に上 昇し, その後も徐々に上昇を続け, 3 力月後には $4.00 \mathrm{~mm}$ に達した。錠剤硬度は加温下 $\left(40^{\circ} \mathrm{C}\right)$ では 経時的にわずかに低下する傾向を示し，加湿下（25 ${ }^{\circ} \mathrm{C} ， 75 \%$ R.H.) では開始時の $82.0 \mathrm{~N}$ から 0.5 力月 
で $54.4 \mathrm{~N}$ にまで低下し, その後徐々に低下を続け 3 力月では $42.9 \mathrm{~N}$ になった。これらの結果から, 錠剂物性は加温条件に比べ加湿条件の影響を大きく 受けることが判明した．加湿条件下における錠剤硬 度の経時変化と錠剤厚みの経時変化との関係は同様 の傾向を示した。これは加湿条件下では錠剤中に含 まれている崩壊剤が水分を吸収し膨潤することによ り，錠剤内部の空隙が大きくなり，錠剤中の接触点 数が減少すると考えられる。したがって，錠剤厚み の経時的上昇に相関し錠剤硬度が低下したものと推 察された。しかし，加湿条件下 3 カ月目においても 錠剂硬度は $42.9 \mathrm{~N}$ であり, 取り扱い上十分な硬度 も持つ錠剤であると考えられた。

\section{結論}

NIL 固体分散体錠の温度，湿度及び光に対する 無包装状態での安定性を調べた。固体分散体技術の 利用により溶解性の改善が図られた NIL 固体分散 体錠剂は，無包装状態で温度及び湿度に暴露した条 件でも開始時と変わらない溶出性を示した。NIL は開始時と同様に保存期間中も非晶質として存在す ることが粉末 X 線回折により示された。錠剤中に は NIL, cl-PVP, MC の他に乳糖，低置換度ヒドロ キシプロピルセルロース，ステアリン酸マグネシウ ムが存在するが，NILの非晶質状態はこれらの添 加剂に対しても安定であることが認められた。ま
た，定量值は温度，湿度及び光に暴露し保存したす べての時点で約 $99 \%$ 以上であり，化学的安定性も 良好であった。錠剤物性は温度に比べて湿度の影響 を受け，加湿下では錠剤重量の増加，厚みの増加， 硬度の低下が観察された。錠剤硬度は錠剤中の崩壊 剂が水分を吸収し膨潤するため厚みが増加し，その 結果硬度が低下するものと考えられた。

\section{REFERENCES}

1) Serajuddin A. T. M., J. Pharm. Sci., 88, 1058 -1066 (1999).

2) Imaizumi H., Nambu N., Nagai T., Chem. Pharm. Bull., 31, 2510-2512 (1983).

3) Sugimoto I., Sakai K., Kuchiki A., Ishihara T., Nakagawa H., Chem. Pharm. Bull., 30, 4479-4488 (1982).

4) Nishioka Y., Iyaku Journal, 39, 850-854 (2003) .

5) Hirasawa N., Ishise S., Miyata H., Danjo K., Drug Develop. Ind. Pharm., 29, 997-1004 (2003).

6) "Zyouzai, Kapuseruzai no Muhousouzyoutaideno Anteiseizyouhou," Iyaku-Journal Sha, Japan, 2001, pp. 9-14.

7) Hirasawa N., Ishise S., Miyata H., Danjo K., Drug Develop. Ind. Pharm., 29, 339-344 (2003). 